\title{
EFFECT OF IONISED (ELECTROLYSED) WATER ON THE RAT EMBRYO DEVELOPMENT
}

\author{
Jolita STANKEVIČ ${ }^{1}$, Aistė AUDICKAITE் ${ }^{1}$, Simona ŠILOVE ${ }^{1 *}$, Valdas ŠIMČIKAS ${ }^{2}$, \\ Henrikas CESIULIS ${ }^{3}$, Grita SKUJIENE ${ }^{4}$, Virginija BUKELSKIENE் ${ }^{5}$, \\ Violeta ŽALGEVIČIENË $\dot{1}^{1}$, Janina TUTKUVIENE ${ }^{1}$ \\ ${ }^{1}$ Department of Anatomy, Histology and Anthropology of the Institute of Biomedical Sciences, \\ Faculty of Medicine, Vilnius University, Čiurlionio g. 21/27, LT-03101, Vilnius, Lithuania \\ ${ }^{2}$ Joint Stock Company "Water research", Žirmünų g. 106, LT-09121, Vilnius, Lithuania \\ ${ }^{3}$ Department of Physical Chemistry of the Faculty of Chemistry and Geosciences, Vilnius University, \\ Naugarduko g. 24, LT-03225, Vilnius, Lithuania \\ ${ }^{4}$ Department of Zoology of the Institute of Biosciences, Life Sciences Center, Vilnius University, \\ Sauletekio al. 7, LT-10223, Vilnius, Lithuania \\ ${ }^{5}$ Department of Biological Models of the Institute of Biochemistry, Life Sciences Center, \\ Vilnius University, Saulètekio al. 7, LT-10223, Vilnius, Lithuania
}

Received 05 June 2019; accepted 18 November 2019

\begin{abstract}
The aim of this study was to investigate the effects ionised water has on embryonic development using Wistar rat animal model. For that purpose, alkaline and acidic water was prepared with a domestic water ioniser. It was found that the concentrations of $\mathrm{Cl}^{-}, \mathrm{SO}_{2}{ }^{-}$ions increased in acidic water, while in alkaline water, $\mathrm{Ca}^{+}$concentration decreased and halogenated hydrocarbon concentrations exceeded permitted levels. The animals were given test alkaline and acidic water, as well as tap water as control. After three months, female rats were mated. On the 21st day of gestation, they were euthanized and subjected to Caesarean sections; the number of live and dead fetuses was recorded. The fetuses were examined for external or visceral malformations and skeletal abnormalities. The data showed that embryo death was higher in acidic and alkaline experimental groups in comparison to the control group. The fetuses in both test groups were significantly shorter than in the control group. Long bones of fetal hind and front limbs were shorter in the acidic group in comparison to the control group. Retardation of limb osteogenesis was expressed in the acidic group fetuses. Therefore, in our model, ionised water had a negative effect on the embryonic development.
\end{abstract}

Keywords: alkaline and acidic water, electrolysis, rat, embryonic development, water cleaning technologies.

\section{Introduction}

Water is the most important substance, which determines survival of all living beings. In the organism, it has a number of roles: it serves as a solvent, temperature buffer, metabolite, living environment, etc. However, natural water is not chemically pure $\mathrm{H}_{2} \mathrm{O}$. Atmospheric precipitation, rocks and sediments, through which water is filtered, play a key role in the formation of underground freshwater. Therefore, the variety of chemical compounds, found in drinking water, depends on the chemical composition of the rock (Lack, 1999). Consumption of water also determines the supply of any minerals it contains. Research suggests that 14 out of 21 mineral elements required for humans are essential for good health. Different combinations of these elements are responsible for managing normal functioning of the body, i.e. bone and membrane structure $(\mathrm{Ca}, \mathrm{P}, \mathrm{Mg}, \mathrm{F})$, water and electrolyte balance $(\mathrm{Na}$, $\mathrm{K}, \mathrm{Cl}$ ), metabolic catalysis ( $\mathrm{Zn}, \mathrm{Cu}, \mathrm{Se}, \mathrm{Mg}, \mathrm{Mn}, \mathrm{Mo}$ ), oxygen binding (Fe), and hormone functions (I, Cr) (World Health Organization, 2005). However, though most of the chemical elements, present in water, are required for a healthy functioning of a human body, surplus in these elements may lead to various diseases and functional problems; thus, the amount of these elements allowed in drinking water is regulated and limited.

Lithuania is considered among the leaders in EU in terms of water purity (LRP, 2016). Specialists claim that

${ }^{*}$ Corresponding author. E-mail: simona.silove@gmail.com 
unpolluted deep water aquifers in Lithuania can be envied by most of the countries for groundwater quality, chemical composition and microbiological indicators. The water is not contaminated with such trace elements as iodine, while others, e.g. fluoride, are very unevenly distributed throughout the country (Klimas \& Mališauskas, 2008). Nitrate, commonly associated with agricultural activities, is also found in very small quantities in Lithuanian groundwater. The same applies to other north European countries, such as Norway, Sweden, Finland, Estonia, and Latvia. It is believed that this is due to frozen ground in winter time, when the land is not arable, thus cannot be polluted with fertilisers and pesticides, the surplus of which might seep into the groundwater (Flem, Reimann, Birke, Banks, \& Filzmoser, 2015).

Moreover, in Europe both surface (from rivers or lakes) and ground water is used for public water supply, while in some countries (Lithuania, Denmark, and Austria) mostly underground water is used for drinking (Volker \& Borchardt, 2019; Flem et al., 2015). Most Lithuanian waters require no treatment, while those requiring some form of purification, are treated with natrium hypochlorite solution, which is considered safe for the environment and people (Vilniaus vandenys, 2016). Still, popular literature and the Internet abound with articles and advertising projects that recommend water treatment with water ionisers, which through the process of electrolysis produce two types of water: acidic (dead) and alkaline (living) (Laucevičius, 2009).

It is known that naturally, with the help of the solar energy, electrolysis occurs in plants and algae. In industry, electrolysis is performed to clean and preserve metallic objects from corrosion, while in the future even hydrogen might be produced by electrolysis as an alternative to fossil fuel (Santos et al., 2019; Rashid, Al Mesfer, Naseem, \& Danish, 2015). Meanwhile, some people believe that electrolysis makes water better and that drinking it may cure many different illnesses. The somewhat popular alkaline diet adds to this believe. However, according to Fenton and Huang (2016), there is no proof that alkaline diet or alkaline water, as promoted by sales agents selling water alkalinisers, has any effect on cancer prevention or treatment.

Still, authors who have been experimenting with living organisms in the hope that alkaline ionised water can work as a protection against diseases stemming from oxidative stress - diabetes, cancer, arteriosclerosis, neurodegenerative diseases, and adverse effects of hemodialysis found that alkaline water is actually beneficial for human health (Xue et al., 2014; Ignacio, Joo, \& Lee, 2012; Shirahata, Hamasaki, \& Teruya, 2012). In addition, some authors brought acid-base hypothesis into view, which suggests that an overly acidic diet (high in protein and grains) leads to chronic diseases and bone health problems, thus, raising the body $\mathrm{pH}$ through alkaline diet and balancing the acid-base ratio could prevent osteoporosis and other related diseases (Dawson-Hughes, 2016; Xu et al., 2016; Fenton, Eliasziw, Lyon, Tough, \& Hanley, 2008). However, as the authors state, the results on acid-base hypothesis are inconclusive and require further investigations (DawsonHughes, 2016; C. J. Fenton, T. R. Fenton, \& Huang, 2017; Fenton et al., 2008)

In nature, high levels of either acidity or alkalinity can destroy life. Acid rains affect the soil, which in turn becomes less fertile and has a negative effect on microorganisms, flora and fauna living on it. Likewise, contaminants responsible for air pollution, such as nitrogen oxides and sulphur dioxides - waste product of manufacturing, transportation, mining and agriculture - when introduced into water, transform into acids and significantly affect water's pH levels (Osman, 2018; Weldeslassie, Naz, Singh, \& Oves, 2018). In the presence of such information, the authors of this study found it important to investigate the effect electrolysis-altered water has on living organisms.

It is known that during electrolysis, ions distribute unevenly in the solution. Anions $\mathrm{Cl}^{-}, \mathrm{SO}_{2}^{-}$, $\mathrm{NO}^{-}$migrate towards the anode, where oxidation reactions take place, producing free chlorine and oxygen gas. Depending on the composition of the electrolysed solution, various salts, sulphuric or nitric acids form, and the $\mathrm{pH}$ value falls below 7. Meanwhile, cations migrate towards the cathode, where reduction occurs. Depending on the alkalinity of the solution, $\mathrm{Ca}_{2}{ }^{+}$and $\mathrm{Mg}^{+}$ions might form low solubility hydroxides (resulting in turbidity) whereas sodium and potassium stay in the solution and form soluble sodium and potassium hydroxides. Potassium hydroxide begins to dominate the solution, and the $\mathrm{pH}$ value increases to 8-9.

Normally, halogenated hydrocarbons are not found in nature, as they are a product of human activity. In water, halogenated hydrocarbons can form after chlorination or by other means of water disinfection or electrolysis. Free chlorine, which forms during electrolysis, reacts with water, bromide, and organic substances, resulting in a variety of halogenated compounds - usually haloforms. Concentrations of free chlorine and haloforms are directly dependent on the composition of water being electrolysed (especially the initial concentration of $\mathrm{Cl}^{-}$), as well as on the duration of electrolysis.

According to the proponents of water ionisers, acidic water produced in these devices is a natural bactericide and pesticide (Bui et al., 2017; Sun, Zhang, Chen, \& Han, 2012; Abbasi \& Lazarovits, 2006). They also claim that alkaline water is better in neutralising stomach gastric acid, detoxifies the organism, and acts like a natural antioxidant and alkalizing substance due to a large content of oxygen and negative oxidation-reduction potential (Mousa, 2016; Laucevičius, 2009). There are many popular and scientific articles about the benefits of electrolysed water (Weidman et al., 2016; Koufman \& Johnston, 2012; Shirahata et al., 2012; Laucevičius, 2009; Shirahata et al., 1997). Because of that, significant part of society now claims to have found a surprising "drug" for treating many different ailments. However, there is little research on the adverse effects electrolysed water has on living organisms (El-Fiky, 2002; Merne, K. J. Syrjanen, \& S. M. Syrjanen, 2001; Watanabe \& Kishikawa, 1998a; Watanabe et al., 1998b; Watanabe, Kishikawa, \& Shirai, 1997). 
Thus, it can be argued that there is a lack of aggregated studies on electrolysed water effect on the whole organism. Likewise, not much is known how electrolysed water affects the development of offspring. Therefore, due to deficiency of scientific evidence supporting the safety of electrolysed water, and due to its popularity in Lithuania and other countries, the aim of this study was to assess the effects of ionised (electrolysed) water on the embryonic development using Wistar rats as a test model. Our goal was to evaluate the formation of the offspring of female rats, which were given acidic and alkaline water before and during pregnancy.

\section{Materials and methods}

\subsection{Water electrolysis}

Tap water provided by "Vilniaus vandenys" Ltd (Lithuania) was used in this study. To produce alkaline and acidic water, ordinary tap water was treated with a domestic water ioniser ("PTV-KL") for 10 and 20 min respectively, according to manufacturer's instructions.

\subsection{Measurement of main ions and volatile halogenated hydrocarbons in the water}

The ion analysis was carried out using Ion Chromatograph DIONEX IC-1000 according to Standards ISO 14911 (Cations) and ISO 10304-1 (Anions).

Haloform analysis was carried out by Gas Chromatograph DANI GC 1000 using Head Space injection technique according to Standard ISO 10301. The samples were taken from sealed vials in which the ratio of water volume to air volume was fixed. In this study, $20 \mathrm{~mL}$-sized vials were filled with $10 \mathrm{~mL}$ of samples. The temperature of the vials was stabilized in a thermostatic system at $70{ }^{\circ} \mathrm{C}$ to achieve specified equilibrium conditions. After reaching equilibrium with water, an electron capture detector was used for gas chromatography in the sampling vials.

\subsection{Animals}

In this study, 3 months old Wistar rats were used. Approval of Ethics Committee and permission for the experimentation was received from the State Food and Veterinary Service of Lithuania, No 1; 14-01-2013. The experiment was designed in accordance to the requirements stated in 2010/63/EU Directive and Order of the Lithuanian State Food and Veterinary Service Director No B1-866; 31-12-2012. Wistar rats were obtained from and animal experiment was carried out in the Department of Biological Models, Vilnius University, Institute of Biochemistry (Lithuania).

\subsection{Experimental methodology}

Three months before mating, female rats were divided into three groups and given different types of electrolysed water: alkaline $(\mathrm{n}=10)$ or acidic $(\mathrm{n}=10)$, and tap water as control $(n=10)$. During this period and at the time of gestation, rats were provided with standard food for rodents and electrolysed (or tap) water ad libitum. The animals were weighed regularly.

After three months, female Wistar rats were mated overnight with males of the same clone. The following morning, vaginal smears were subjected to a microscopic examination in order to determine the presence of sperm. The day of sperm detection in vaginal smears was designated as day 0 of gestation. On the 21 st day of gestation, the animals were euthanized and subjected to Caesarean sections. The uteri were removed and opened; dead and live fetuses were recorded in the uterine horn to determine post-implantation mortality indices.

\subsection{Measurement of mother rat blood open circuit potential}

Values of open circuit potential (OCP) were calculated from recorded time dependencies of potential differences measured directly between platinum electrode and reference electrode (saturated $\mathrm{Ag}, \mathrm{AgCl} / \mathrm{Cl}^{-}$electrode) immersed into the sample of blood. The volume of the sample was $\sim 1 \mathrm{~mL}$. The dependencies were recorded by means of programmable potentiostat/galvanostat AUTOLAB N302. Heparin was used as the anticoagulant of blood.

\subsection{Analysis of fetuses}

To assess the effects of ionised (electrolysed) water on the embryonic development, external and internal physical features of the fetuses were evaluated. For that purpose, the fetuses were weighed and measured; half fetuses of every female (alkaline $(\mathrm{n}=35)$, acidic $(\mathrm{n}=20)$, control $(\mathrm{n}=47)$ ) were fixed in Bouin's solution for subsequent examination for external and visceral malformations. In order to render the skeleton visible, another set of fetuses (alkaline $(\mathrm{n}=34)$, acidic $(\mathrm{n}=21)$, control $(\mathrm{n}=48)$ ) was fixed in ethanol. For visceral malformation analysis, fetuses were sliced using Hayes technique. Using an eyepiece micrometre attached to a stereomicroscope (MBS-1), internal organs of the fetuses (liver, kidney, heart, lungs, brain and other) were investigated, and length of ossification centers of the fetal limb bones was measured in the middle of diaphysis of long tubular bones (Hayes, 1994). The fetuses of the control group were prepared and examined in the same way as the experimental ones.

\subsection{Statistical analysis}

All the data are expressed as mean \pm standard deviation (SD). Two-tailed Student's t-test was performed to ascertain statistical significance $(p<0.05)$ in differences between results of experimental and control groups. For the evaluation of ion concentrations in the water and water's effect on bone length, one-way analysis of variance (one way-ANOVA) was used, followed by Tukey's multiple comparisons post-hoc. 


\section{Results}

\subsection{Ion concentration in water and water $\mathrm{pH}$ after electrolysis}

In the experiments, after tap water electrolysis for 10 and 20 min, concentration of main ions, volatile halogenated hydrocarbons and $\mathrm{pH}$ were analysed. The results revealed, that $\mathrm{pH}$ of electrolysed water assay was significantly different from the tap water $(\mathrm{pH}-7.91)$ used: $\mathrm{pH}$ of acidic water was 3.38 , and of alkaline - 10.14. Also, the concentration of $\mathrm{Ca}^{+}$was significantly reduced in alkaline water as compared to tap water (Figure 1a and $1 \mathrm{~b}$ ).

The study of halogenated hydrocarbons in electrolysed water demonstrated increased concentrations of chloroform $(\mathrm{CHCl} 3)$ and bromodichloromethane $(\mathrm{CHBrCl} 2)$ in both acidic and alkaline water (Table 1). After ionisation, the concentration of chloroform in alkaline water increased from 0.38 (after $10 \mathrm{~min}$ ) to $0.63 \mu \mathrm{g} / \mathrm{l}$ (after $20 \mathrm{~min}$ ), while in acidic water, it decreased from 25.20 (after $10 \mathrm{~min}$ ) to $23.10 \mu \mathrm{g} / \mathrm{l}$ (after $20 \mathrm{~min}$ ). Similarly, the concentration of bromodichloromethane increased in acidic water from 10.50 to $16.30 \mu \mathrm{g} / \mathrm{l}$. Also, an increase of bromoforms was detected in acidic water - from 0.89 to $1.49 \mu \mathrm{g} / \mathrm{l}$.

\subsection{Blood OCP, blood and urine $\mathrm{pH}$ in mother rats}

In the medical, biological, and ecological literature, an OCP of platinum electrode placed into a test medium against a certain reference electrode is considered as the redox potential of the medium. In this case, "redox potential" means the OCP of the electrode immersed into studied biological medium, such as blood or urine.

To evaluate the impact of ionised water on the physical status of mother rats, blood and urine samples were collected just before mating. It was found that for rats in acidic and alkaline groups, the values of OCP in blood decreased by $\sim 0.03 \mathrm{~V}$ : from $0.165 \mathrm{~V}$ in control group to $0.135 \mathrm{~V}$ in groups, which consumed ionised water.

Furthermore, urine $\mathrm{pH}$ of rats, which were given electrolysed water for 3 months, ranged as follows: $7.59 \pm 0.40$ in acidic, and $7.23 \pm 0.53$ in alkaline groups. Urine $\mathrm{pH}$ of control rats, which were given tap water, was $7.35 \pm 0.58$. Therefore, generally urine $\mathrm{pH}$ did not differ significantly between the experimental and control groups $(p>0.05)$.

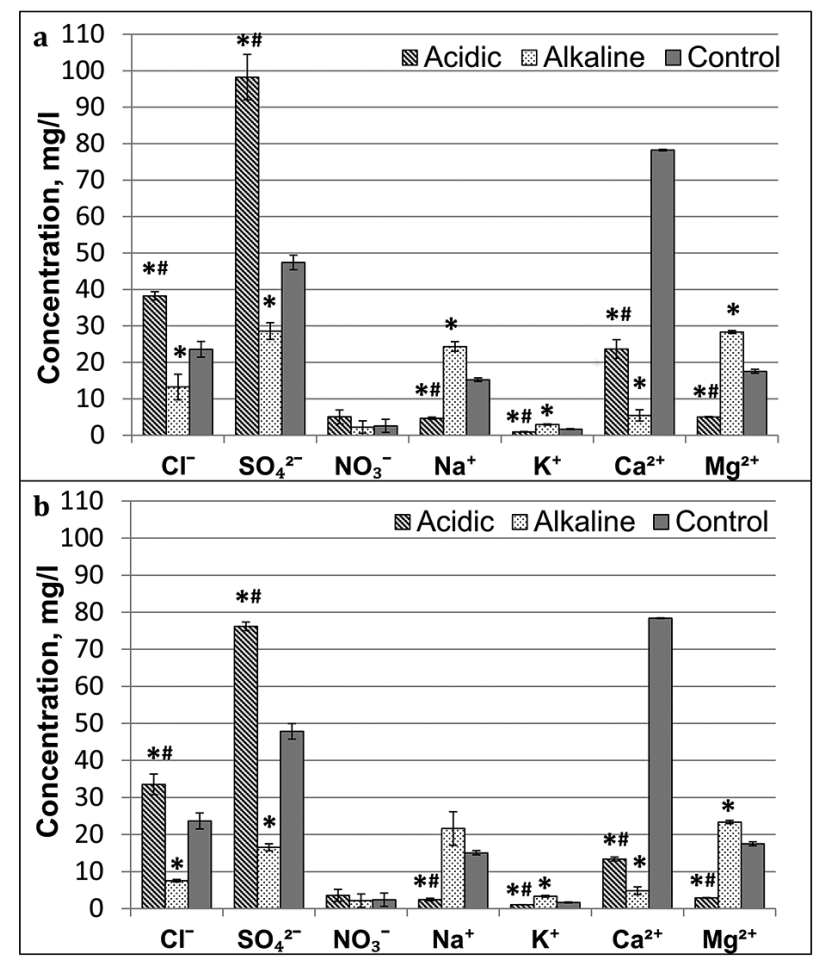

Figure 1. Ion $\left(\mathrm{Cl}^{-}, \mathrm{SO}_{2} 2^{-}, \mathrm{NO}^{-}, \mathrm{Na}^{+}, \mathrm{K}^{+}, \mathrm{Ca}^{+}, \mathrm{Mg}^{+}\right)$ concentrations in acidic, alkaline and control tap water $(\mathrm{mg} / \mathrm{l})$; a - after 10 min.; b - after 20 min. of electrolysis; mean \pm S.D; ${ }^{*} \mathrm{p}<0.05$ when compared to control; $\# \mathrm{p}<0.05$ when compared to alkaline group

Similarly, mother rats' blood $\mathrm{pH}$ did not differ in experimental and control groups, when compared $(\mathrm{p}>0.05)$ : blood $\mathrm{pH}$ of alkaline group was $7.78 \pm 0.17$, acidic group $7.80 \pm 0.17$, and control group $-7.80 \pm 0.10$. Thus, the data suggests that ionised water did not affect the acidity or basicity of experimental rats' blood.

\subsection{Body weight of differently watered rats}

The analysis of rats' body weight gained during three months revealed such results: animals given alkaline water gained $40.5 \pm 18.05 \mathrm{~g}$, acidic water $-32.4 \pm 16.90 \mathrm{~g}$, while during the same time rats in the control group gained $52.4 \pm 17.52 \mathrm{~g}$. Thus, rats in both experimental groups gained less weight than those in the control group, the lowest weight gain being observed in the acidic group. Nonetheless, there were no statistically significant

Table 1. Dssolved halogenated hydrocarbons (chloroform, bromodichloromethane, chlorodibromomethane, bromoform) in control (tap water), alkaline and acidic water after 10 and $20 \mathrm{~min}$ of electrolysis $(\mu \mathrm{g} / \mathrm{l})$

\begin{tabular}{|c|c|c|c|c|c|}
\hline & & Chloroform $(\mu \mathrm{g} / \mathrm{l})$ & $\begin{array}{l}\text { Bromodichloro- } \\
\text { methane }(\mu \mathrm{g} / \mathrm{l})\end{array}$ & $\begin{array}{l}\text { Chlorodibro- } \\
\text { momethane }(\mu \mathrm{g} / \mathrm{l})\end{array}$ & Bromoform $(\mu \mathrm{g} / \mathrm{l})$ \\
\hline Control & Tap water & $<0.1$ & $<0.1$ & $<0.1$ & $<0.1$ \\
\hline \multirow{2}{*}{ Alkaline water } & 10 min electrolysis & $0.38 \pm 0.02$ & $0.13 \pm 0.04$ & $<0.1$ & $<0.1$ \\
\hline & 20 min electrolysis & $0.63 \pm 0.16$ & $0.13 \pm 0.01$ & $<0.1$ & $<0.1$ \\
\hline \multirow{2}{*}{ Acidic water } & 10 min electrolysis & $25.20 \pm 0.99$ & $10.50 \pm 2.84$ & $5.04 \pm 1.38$ & $0.89 \pm 0.11$ \\
\hline & 20 min electrolysis & $23.10 \pm 6.08$ & $16.30 \pm 4.66$ & $12.40 \pm 1.41$ & $1.49 \pm 0.01$ \\
\hline
\end{tabular}



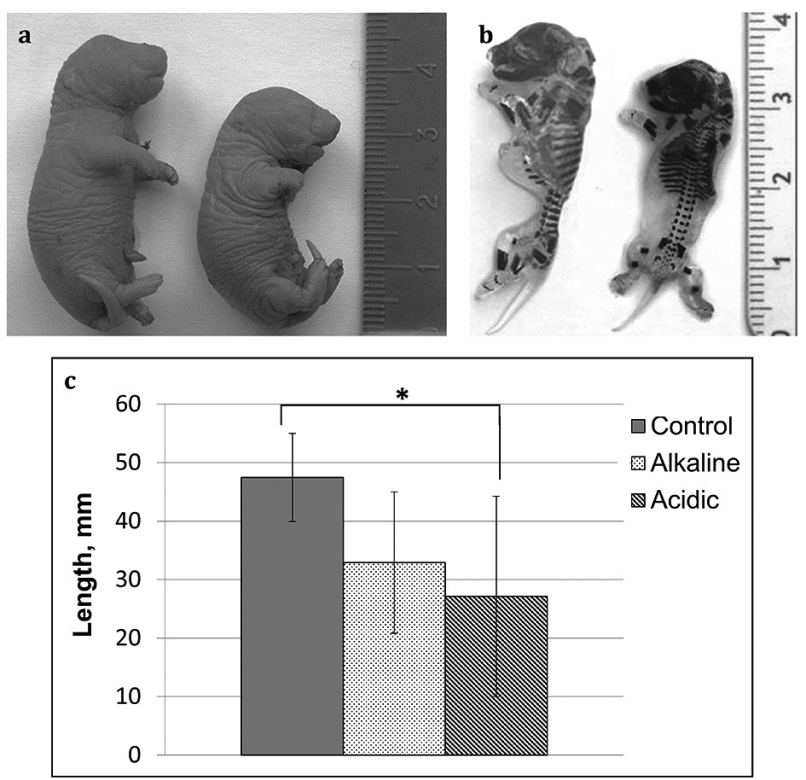

Figure 2. Ionised water effect on fetus length:

a - general view of control (left) and acidic (right) groups fetuses; $\mathrm{b}$ - fetuses of control (left) and acidic (right) groups represent the retardation of bone development in acidic group fetuses; c - comparison of fetuses' length in control, alkaline and acidic groups; acidic group fetuses were significantly shorter $(\mathrm{p}<0.05)$ compared to control

differences between both experimental groups and control group ( $\mathrm{p}>0.05$ ).

It also should be noted that rats in both experimental groups tended to consume less water (acidic or alkaline) than rats in control group, which consumed tap water.

\subsection{Embryonic development}

The main objective of this study was to assess the effects of ionised (electrolysed) water taken by the mother rats on the embryonic development. In assessing the viability of rat embryos, the data of this study revealed that embryo death rate increased in both acidic $(27.0 \%)$ and alkaline (10.1\%) groups compared to the control group (0\%). In addition, it was detected that female rats, which had been given ionised water, had $10.14 \%$ of embryo resorptions. On the contrary, no embryo resorption was detected in rats, which consumed tap water.

Moreover, electrolysed water did not cause any noticeable developmental defects of external or internal organs of the fetuses (Figure $2 \mathrm{a}$ and $2 \mathrm{~b}$ ). However, ionised water had a noticeable effect on the size of fetuses: rat fetuses of both experimental groups were shorter than those of the control group; even more, acidic group fetuses were significantly shorter $(\mathrm{p}<0.05)$ compared to the controls (Figure 2c), even though their weight did not differ.

While evaluating ossification centers of front and hind limb bones in coloured skeletons of the fetuses, it was found that acidic water did influence ossification of the long bones of limbs - they were shorter in comparison to the control group $(\mathrm{p}<0.05)$ (Figure $3 \mathrm{a}$ and $3 \mathrm{~b})$. On the other hand, ossification of the long bones of the fetuses from alkaline group had no disruptions in skeletal development, and was not statistically different from the fetuses in the control group $(\mathrm{p}>0.05)$.

\section{Discussion}

Water ionisation supporters claim that alkaline water neutralizes bodily acids and helps with the prevention of diseases, however, according to Vorman and Goedecke (2002), various buffer systems are responsible for a stable $\mathrm{pH}$ of body fluids, thus the acidity or alkalinity of food and drink is irrelevant, as it will not change the $\mathrm{pH}$ values of the body. In agreement with that, the results of this study indicate that urine and blood $\mathrm{pH}$ of the rats given alkaline water did not become more alkaline. Moreover, female rats which were given acidic and alkaline water gained less weight, though no statistically significant difference between experimental and control groups was found. These results could be compared to those of Watanabe et al. (Watanabe \& Kishikawa, 1998a; Watanabe et al., 1998b; Watanabe et al., 1997), who investigated how alkaline water changed body weight, and analysed biochemical parameters of the blood, as well as hearts of pregnant rats and their offspring. Their study demonstrated that alkaline water leads to increased body weight of rats and some of their organs, erythrocyte haemolysis,

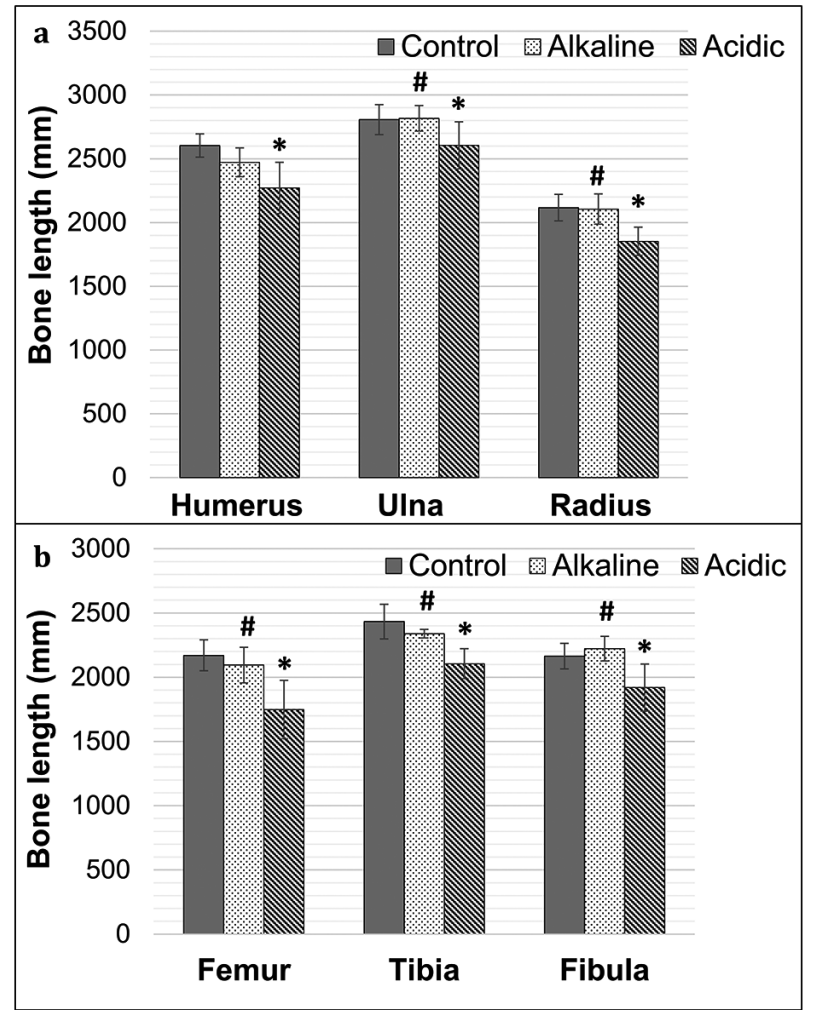

Figure 3. Effect of electrolysed water on the ossification of the fetuses long bones of limbs: a - length of front leg bud in control, alkaline and acidic group fetuses; b - length of hind leg bud in control, alkaline and acidic group fetuses; mean \pm S.D; ${ }^{*} \mathrm{p}<0.05$ when compared to control; $\# \mathrm{p}<0.05$ when compared to acidic group 
elevated blood potassium, and induced myocardial necrosis and fibrosis.

On the other hand, Massimiliano Magro's et al. (2016) 3-year survival study of alkaline water consumption effects on a population of mice revealed that even though animals which were given alkaline water lived longer, there was no correlation between a risk of diseases and alkaline water consumption. After examining the animals' organs histologically, the authors found that there were no significant differences between mice treated with alkaline water and tap water (Magro et al., 2016). However, it must be taken into consideration that water ionisers produce both alkaline and acidic water, and that there is a permeable membrane between the cameras of the device, where this water is produced.

During electrolysis halogenated hydrocarbons (chloroform, bromodichloromethane, chlorodibromoethane, and bromoform) increase in concentration in the water. Out of these, the levels of chloroform are usually the most elevated. Through the aforementioned membrane, part of the chlorine ions migrate from acidic to alkaline water. It is well known that chloroform is used for water disinfection and that when its concentration increases in water, together with bromodichloromethane, it may become carcinogenic and increase the risk of malignancies - colon cancer, premature births or embryonic anomalies (Benmarhnia, Delpla, Schwarz, Rodriguez, \& Levallois, 2018; Abdelhalim, Salaheldeen, Idris, Abdelsalam, \& Sabahelkhier, 2016; Hrudey et al., 2015; Villanueva, Cordier, Font-Ribera, Salas, \& Levallois, 2015; Chen, Lin, Duh, Chou, \& Hsu, 2011; Florentin, Hautemaniere, \& Hartemann, 2011; Legay et al., 2011; Mills et al., 1998). Our study revealed that even after 10 minutes of water electrolysation, halogenated compound levels of methane and ethane (haloforms) toxic for living organisms - increased in the water. Thus, even though in the present study electrolysed water did not cause any noticeable developmental defects of the external or internal organs of the fetuses, nevertheless, this water had a significant impact on fetus size. Significant differences between ossification centers in long bones of fetuses were also detected.

Various literature sources point out that embryonic ossification depends on genetics or is affected by oxidative stress, diet, hormones, various environmental factors, and maternal physical activity (Hu et al., 2018; Jensen et al., 2017; Fadel, Sequeira, Abu-Hijleh, Obeidat, \& Salem, 2012; Ornoy, Rand, \& Bischitz, 2010; Rauch \& Schoenau, 2001; Fadel \& Persaud, 1993). Likewise, limb ossification disorders can be induced by teratogenic substances, such as azathioprine, which impairs the interaction between the apical ectodermal ridge and the progress zone, i.e., the morphogenetic zones located in the distal part of the limb (Zukiene, Zalgeviciene, \& Rizgeliene, 2003). The results of this study demonstrated that, prior to mating, mother rats, which were given acidic water, tended to weigh less. Stress indicators, such as rough coat and bloody tears, were also evident in this animal group. Such physical changes of mother rats could have been the cause of embryo growth retardation and the slowing down of their bone development. In addition, reduced $\mathrm{Ca}_{2}{ }^{+}$concentration in ionised water could also have led to abnormal ossification. Also, the possibility that halogenated hydrocarbons detected in water after electrolysis could be the cause of ossification retardation and other ossification disorders in the embryo must equally be taken into consideration.

Furthermore, in medical science, many attempts were made to estimate the redox properties of blood, other biological liquids, and tissues by measuring OCP. In a previous study done by the authors, rat blood OCP values decreased by $\sim 0.03 \mathrm{~V}$ for rats in acidic and alkaline groups in comparison to the control group (Audickaite et al., 2014). Usually, such values indicate no presence of pathology in human blood (Khubutiya et al., 2010). However, if pathology was detected, notable deviations from the average values of OCP would appear, and differences between OCP could reach up to $0.1 \mathrm{~V}$ (Vormann \& Goedecke, 2002). Since many homeostatic processes are electrochemical, when their activity increases, and changes in the composition of potential forming system appear, OCP levels vary more significantly. However, evaluation according to the Nernst equation reveals that the ratio of oxidized molecules to reduced molecules in the rats' blood decreases up to 3 times, and such a decrease is probably enough to cause pathology in rats.

\section{Conclusions}

1. The study revealed that after electrolysis the concentrations of $\mathrm{Cl}^{-}, \mathrm{SO}_{2}^{-}$ions increased in acidic water, while in alkaline water $\mathrm{Ca}^{+}$concentration decreased and halogenated hydrocarbon concentrations exceeded permitted levels.

2. Rats, which were given alkaline and acidic water for 3 months, tended to gain less weight in comparison to those that drunk tap water.

3. Blood and urine $\mathrm{pH}$ differences were not statistically significant between groups; however, the urine of rats, which had been given alkaline water, had a tendency to acidify.

4. Neither alkaline nor acidic water had any effect on rat blood OCP.

5. Fetal analysis revealed that offspring of mother rats that had been watered with electrolysed water were smaller than those, whose mothers drank tap water.

6. Long bones of hind and front limbs of the fetuses from experimental groups (in particular - acidic) were noticeably shorter in comparison to the ones in control group.

7. In this model, ionised water had a negative effect on the development of embryos of mother rats which were given ionised (electrolysed) water.

\section{Conflict of interest}

The authors declare no conflict of interest. 


\section{References}

Abbasi, P. A., \& Lazarovits, G. (2006). Effect of acidic electrolysed water on the viability of bacterial and fungal plant pathogens and on bacterial spot disease of tomato. Canadian Journal of Microbiology, 52, 915-923. https://doi.org/10.1139/w06-048

Abdelhalim, M. I., Salaheldeen, Y. M., Idris, O. F., Abdelsalam, E. B., \& Sabahelkhier, M. K. (2016). Histopathological effect on different rat tissues induced by the trihalomethanebromoform administered in drinking water. Nova Journal of Medical and Biological Sciences, 5, 1-7.

https://doi.org/10.20286/nova-jmbs-050280

Audickaitė, A., Stankevič, J., Šimčikas, V., Cesiulis, H., Jarašienè, R., Bukelskienè, V., Žalgevičienè, V., \& Tutkuvienė, J. (2014). Jonizuoto (elektrolizuoto) vandens ịtaka žiurkių patelių fizinei būklei (eksperimentinis tyrimas) [The influence of ionized (electrolysed) water on physical status of female rats (experimental study)]. Sveikatos mokslai [Health Sciences], 24, 46-51. https://doi.org/10.5200/sm-hs.2014.024

Benmarhnia, T., Delpla, I., Schwarz, L., Rodriguez, M., \& Levallois, P. (2018). Heterogeneity in the relationship between disinfection by-products in drinking water and cancer: a systematic review. International Journal of Environmental Research and Public Health, 15(5), 979.

https://doi.org/10.3390/ijerph15050979

Bui, V. N., Nguyen, K. V., Pham, N. T., Bui, A. N., Dao, T. D., Nguyen, H. T., Trinh, D. Q., Inui, K., Uchiumi, H., Ogawa, H., \& Imai, K. (2017). Potential of electrolysed water for disinfection of foot-and-mouth disease virus. Journal of Veterinary Medical Science, 79, 726-729.

https://doi.org/10.1292/jvms.16-0614

Chen, M. J., Lin, C. H., Duh, J. M., Chou, W. S., \& Hsu, H. T. (2011). Development of a multi-pathway probabilistic health risk assessment model for swimmers exposed to chloroform in indoor swimming pools. Journal of Hazardous Materials, 185, 1037-1044. https://doi.org/10.1016/j.jhazmat.2010.10.011

Dawson-Hughes, B. (2016). Acid-base balance of the diet: implications for bone. In C. M. Weaver, R. M. Daly, \& H. A. Bischoff-Ferrari (Eds.), Nutritional influences on bone health (9th International Symposium). Cham: Springer International Publishing Switzerland.

https://doi.org/10.1007/978-3-319-32417-3_9

El-Fiky, N. K. (2002). The influence of water $\mathrm{pH}$ on the embryonic development of grass carp, Ctenopharyngodon idell. Egyptian Journal of Aquatic Biology and Fisheries, 6, 233-261. https://doi.org/10.21608/ejabf.2002.1760

Fadel, R. A., \& Persaud, T. V. (1993). Ossification of the vertebral column in the offspring of rats exposed to alcohol, acetaldehyde and caffeine. Experimental and Toxicologic Pathology, 45, 51-54. https://doi.org/10.1016/S0940-2993(11)80456-2

Fadel, R. A., Sequeira, R. P., Abu-Hijleh, M. F., Obeidat, M., \& Salem, A. H. (2012). Effect of prenatal administration of therapeutic doses of topiramate on ossification of ribs and vertebrae in rat fetuses. Romanian Journal of Morphology and Embryology, 53, 321-327.

Fenton, T. R., Eliasziw, M., Lyon, A. W., Tough, S. C., \& Hanley, D. A. (2008). Meta-analysis of the quantity of calcium excretion associated with the net acid excretion of the modern diet under the acid-ash diet hypothesis. The American Journal of Clinical Nutrition, 88, 1159-1166.

https://doi.org/10.1093/ajcn/88.4.1159

Fenton, T. R., \& Huang, T. (2016). Systematic review of the association between dietary acid load, alkaline water and cancer. BMJ Open, 6, 1-5.

https://doi.org/10.1136/bmjopen-2015-010438
Fenton, C. J., Fenton, T. R., \& Huang, T. (2017). Further evidence of no association between dietary acid load and disease. The Journal of Nutrition, 147(2), 272.

https://doi.org/10.3945/jn.116.242107

Flem, B., Reimann, C., Birke, M., Banks, D., \& Filzmoser, P. (2015). Inorganic chemical quality of european tap-water: 2. Geographical distribution. Applied Geochemistry, 59, 211-224. https://doi.org/10.1016/j.apgeochem.2015.01.016

Florentin, A., Hautemaniere, A., \& Hartemann, P. (2011). Health effects of disinfection by-products in chlorinated swimming pools. International Journal of Hygiene and Environmental Health, 214, 461-469.

https://doi.org/10.1016/j.ijheh.2011.07.012

Hayes, A. W. (1994). Principles and methods of toxicology. New York: Raven Press.

Hrudey, S. E., Backer, L. C., Humpage, A. R., Krasner, S. W., Michaud, D. S., Moore, L. E., Singer, P. C., \& Stanford, B. D. (2015). Evaluating evidence for association of human bladder cancer with drinking-water chlorination disinfection byproducts. Journal of Toxicology and Environmental Health, Part B, 18, 213-241. https://doi.org/10.1080/10937404.2015.1067661

Hu, H., Zhao, X., Ma, J., Shangguan, Y., Pan, Z., Chen, L., Zhang, X., \& Wang, H. (2018). Prenatal nicotine exposure retards osteoclastogenesis and endochondral ossification in fetal long bones in rats. Toxicology Letters, 295, 249-255.

https://doi.org/10.1016/j.toxlet.2018.07.005

Ignacio, R. M. C., Joo, K.-B., \& Lee, K.-J. (2012). Clinical effect and mechanism of alkaline reduced water. Journal of Food and Drug Analysis, 20, 394-397.

Jensen, V. F. H., Molck, A.-M., Berthelsen, L. O., Andersen, L., Demozay, D., Renaut R., \& Bogh, I. (2017). Gestational hypoglycaemia restricts foetal growth and skeletal ossification in the rat. Journal of Pregnancy and Child Health, 4, 1-11.

Khubutiya, M. S., Evseev, A. K., Kolesnikov, V. A., Goldin, M. M., Davydov, A. D., Volkov, A. G., \& Stepanov, A. (2010). Measurements of platinum electrode potential in blood and blood plasma and serum. Russian Journal of Electrochemistry, 46, 537-541. https://doi.org/10.1134/S1023193510050071

Klimas, A., \& Mališauskas, A. (2008). Boron, fluoride, strontium and lithium anomalies in fresh groundwater of Lithuania. Geologija, 50(2), 114-124.

https://doi.org/10.2478/v10056-008-0015-4

Koufman, J. A., \& Johnston, N. (2012). Potential benefits of $\mathrm{pH}$ 8.8 alkaline drinking water as an adjunct in the treatment of reflux disease. Annals of Otology, Rhinology \& Laryngology, 121, 431-434. https://doi.org/10.1177/000348941212100702

Lack, T. (1999). Water and health in Europe: an overview. BMJ, 318(7199), 1678-1682.

https://doi.org/10.1136/bmj.318.7199.1678

Laucevičius, T. (2009). Jonizuotas vanduo. Gyvenimas be ligų. [Ionised water. Life without diseases]. Kaunas: Obuolys (Lithuania).

Legay, C., Rodriguez, M. J., Sadiq, R., Sérodes, J. B., Levallois, P., \& Proulx, F. (2011). Spatial variations of human health risk associated with exposure to chlorination by-products occurring in drinking water. Journal of Environmental Management, 92, 892-901. https://doi.org/10.1016/j.jenvman.2010.10.056

LRP. (2016). Lithuania's water resources and their protection receive attention in Davos. Vilnius. Retrieved from https://www. lrp.lt/en/press-centr/press-releases/lithuanias-water-resources-and-their-protection-receive-attention-in-davos/24575.

Magro, M., Corain, L., Ferro, S., Baratell, D., Bonaiuto, E., Terzo, M., Corraducci, V., Salmaso, L., \& Vianello, F. (2016). 
Alkaline water and longevity: a murine study. Evidence-Based Complementary and Alternative Medicine, 2016, 1-6. https://doi.org/10.1155/2016/3084126

Merne, M. E., Syrjanen, K. J., \& Syrjanen, S. M. (2001). Systemic and local effects of long-term exposure to alkaline drinking water in rats. International Journal of Experimental Pathology, 82, 213-219.

https://doi.org/10.1111/j.1365-2613.2001.iep188.x

Mills, C. J., Bull, R. J., Cantor, K. P., Reif, J., Hrudey, S. E., \& Huston, P. (1998). Workshop report. Health risks of drinking water chlorination by-products: report of an expert working group. Chronic Diseases in Canada, 19, 91-102.

Mousa, H. A. (2016). Health effects of alkaline diet and water, reduction of digestive-tract bacterial load, and earthing. Alternative Therapies in Health and Medicine, 22, 24-33.

Ornoy, A., Rand, S. B., \& Bischitz, N. (2010). Hyperglycemia and hypoxia are interrelated in their teratogenic mechanism: studies on cultured rat embryos. Birth Defects Research. Part B, Developmental and Reproductive Toxicology, 89, 106-115. https://doi.org/10.1002/bdrb.20230

Osman, K. T. (2018). Management of soil problems. Cham: Springer International Publishing AG.

https://doi.org/10.1007/978-3-319-75527-4

Rashid, M. M., Al Mesfer, M. K., Naseem, H., \& Danish, M. (2015). Hydrogen production by water electrolysis: a review of alkaline water electrolysis, PEM water electrolysis and high temperature water electrolysis. International Journal of Engineering and Advanced Technology, 4, 80-93.

Rauch, F., \& Schoenau, E. (2001). The developing bone: slave or master of its cells and molecules? Pediatric Research, 50, 309-314. https://doi.org/10.1203/00006450-200109000-00003

Santos, B. A. F., Serenario, M. E. D., Pinto, D. L. M. F., Simoes, T. A., Malafaia, A. M. S., \& Bueno, A. H. S. (2019). Evaluation of micro-crack incidence and their influence on the corrosion resistance of steel coated with different chromium thicknesses. Revista Virtual de Quimica, 11, 264-274. https://doi.org/10.21577/1984-6835.20190019

Shirahata, S., Kabayama, S., Nakano, M., Miura, T., Kusumoto, K., Gotoh, M., Hayashi, H., Otsubo, K., Morisawa, S., \& Katakura, Y. (1997). Electrolysed-reduced water scavenges active oxygen species and protects DNA from oxidative damage. Biochemical and Biophysical Research Communications, 234, 269-274. https://doi.org/10.1006/bbrc.1997.6622

Shirahata, S., Hamasaki, T., \& Teruya, K. (2012). Advanced research on the health benefit of reduced water. Trends in Food Science \& Technology, 23, 124-131. https://doi.org/10.1016/j.tifs.2011.10.009

Sun, J. L., Zhang, S. K., Chen, J. Y., \& Han, B. Z. (2012). Efficacy of acidic and basic electrolysed water in eradicating Staphylococcus aureus biofilm. Canadian Journal of Microbiology, 58, 448-454. https://doi.org/10.1139/w2012-005

Villanueva, C. M., Cordier, S., Font-Ribera, L., Salas, L. A., \& Levallois, P. (2015). Overview of disinfection by-products and associated health effects. Current Environmental Health Reports, 2, 107-115. https://doi.org/10.1007/s40572-014-0032-x

Vilniaus vandenys. (2016). Water quality. Retrieved from https:// www.vv.lt/en/quality/\#

Volker, J., \& Borchardt, D. (2019). Drinking water quality at risk: a European perspective. In M. Schroter, A. Bonn, S. Klotz, R. Seppelt, \& Baessler, C. (Eds.), Atlas of ecosystem services. Drivers, risks, and societal responses. Cham: Springer International Publishing AG.

Vormann, J., \& Goedecke, T. (2002). Latent acidosis: overacidification as a cause of chronic diseases. Journal Suisse de Medecine Globale, 14, 90-96.

Watanabe, T., Kishikawa, Y., \& Shirai, W. (1997). Influence of alkaline ionised water on rat erythrocyte hexokinase activity and myocardium. Journal of Toxicological Sciences, 22, 141152. https://doi.org/10.2131/jts.22.2_141

Watanabe, T., \& Kishikawa, Y. (1998a). Degradation of myocardiac myosin and creatine kinase in rats given alkaline ionised water. Journal of Veterinary Medical Science, 60, 245-250. https://doi.org/10.1292/jvms.60.245

Watanabe, T., Shirai, W., Pan, I., Fukuda, Y., Murasugi, E., Sato, T., Kamata, H., \& Uwatoko, K. (1998b). Histopathological influence of alkaline ionised water on myocardial muscle of mother rats. Journal of Toxicological Sciences, 23, 411-417. https://doi.org/10.2131/jts.23.5_411

Weidman, J., Holsworth, R. E., Brossman, B., Cho, G. J., Cyr, J. S., \& Fridman, G. (2016). Effect of electrolysed high-pH alkaline water on blood viscosity in healthy adults. Journal of the International Society of Sports Nutrition, 13(45), 1-13. https://doi.org/10.1186/s12970-016-0153-8

Weldeslassie, T., Naz, H., Singh, B., \& Oves, M. (2018). Chemical contaminants for soil, air and aquatic ecosystem. In M. Oves, M. Z. Khan, \& I. M. I. Ismail (Eds.), Modern age environmental problems and their remediation. Cham: Springer International Publishing AG. https://doi.org/10.1007/978-3-319-64501-8_1

World Health Organization. (2005). Nutrients in drinking water. Geneva. Retrieved from http://www.who.int/water_sanitation_health/dwq/nutrientsindw.pdf?ua=1.

$\mathrm{Xu}, \mathrm{H}$. , Akesson, A., Orsini, N., Hakansson, N., Wolk, A., \& Carrero, J. J. (2016). Modest U-shaped association between dietary acid load and risk of all-cause and cardiovascular mortality in adults. The Journal of Nutrition, 146, 1580-1585. https://doi.org/10.3945/jn.116.231019

Xue, J., Shang, G., Tanaka, Y., Saihara, Y., Hou, L., Velasquez, N., Liu, W., \& Lu, Y. (2014). Dose-dependent inhibition of gastric injury by hydrogen in alkaline electrolyzed drinking water. BMC Complementary and Alternative Medicine, 14, (81), 1-9. https://doi.org/10.1186/1472-6882-14-81

Zukiene, J., Zalgeviciene, V., \& Rizgeliene, R. (2003). The influence of azathioprine on the osteogenesis of the limbs. Medicina, 39, 584-588. 